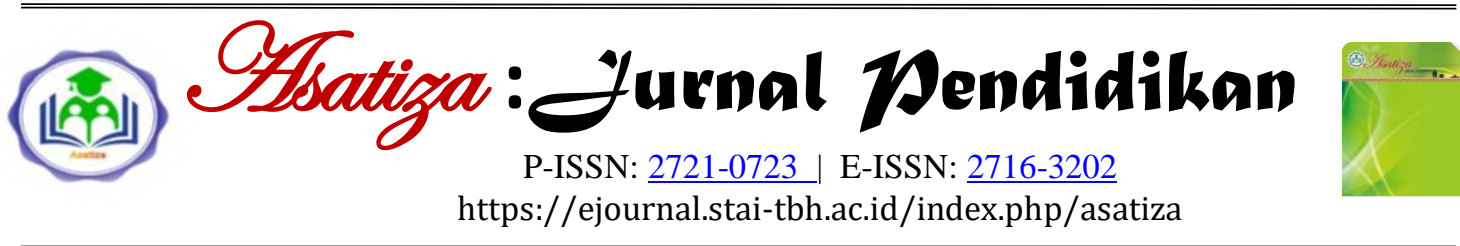

\section{Pendekatan Integralistik sebagai Media Alternatif Inovasi Pendidikan Islam di Era Milenial}

\author{
"Nur Zaytun Hasanah",a, Dhiko Saifuddin Zakly 2,b \\ 1,2, Universitas Islam Indonesia, Sleman, Yogyakarta, Indonesia \\ ${ }^{\mathrm{a}}$ hasanahnurzaytun@gmail.com, ${ }^{\mathrm{b}}$ dhikoblaze@gmail.com
}

\begin{tabular}{|c|c|}
\hline $\begin{array}{l}\text { INFORMA } \\
\text { ARTIKEL }\end{array}$ & \\
\hline Histori Arti & ikel: \\
\hline Diterima : & : 02/08/2021 \\
\hline Direvisi & : 27/09/2021 \\
\hline Disetujui : & : 27/09/2021 \\
\hline Diterbitkan : & : 30/09/2021 \\
\hline
\end{tabular}

Keywords:

Education, Integrated

Approach, Islam,

Millennial

\section{Kata Kunci: \\ Pendidikan, \\ Pendekatan \\ Integralistik, Islam, \\ Milenial}

\section{DOI:}

https://doi.org/10.46963/ asatiza.v2i3.384

\section{*Correspondence}

Author:

hasanahnurzaytun@gmai

$\underline{1 . c o m}$

\begin{abstract}
In the current millennial era, many young Muslim generations are exposed to the millennial effect, which has an impact on emerging behavior. The purpose of this study was to describe an integrated approach as an alternative medium for Islamic education innovation. This research is a descriptive qualitative approach. Data collection techniques used were observation, documentation, and interview. The data were analyzed using Miles Huberman and Saldana's stages of data collection, data condensation, data presentation, and conclusion drawing. The results showed that the integrated approach implemented at SMP IT Salman Al-Farizi Yogyakarta was able to be an alternative media for Islamic education innovation in the millennial era. This integrated approach makes the Islamic faith as its foundation, it also enables teachers to create students who have Islamic personalities, smart, and skillful in mastering science and technology.
\end{abstract}

\begin{abstract}
Abstrak
Pada era milenial saat ini, banyak generasi muda Islam yang terpapar milenial effect, sehingga berdampak pada perilaku yang muncul. Tujuan penelitian ini adalah untuk menginterpretasikan pendekatan integralistik sebagai media alternatif inovasi pendidikan Islam. Penelitian ini merupakan penelitian kualitatif dengan pendekatan penelitian deskripsi kualitatif. Teknik pengumpulan data yang digunakan yaitu metode observasi, metode dokumentasi dan metode wawancara. Teknik analisis data yang digunakan ialah Miles, Huberman dan Saldana dengan tahapan koleksi data, kondensasi data, penyajian data dan penarikan kesimpulan. Hasil penelitian menunjukkan bahwa pendekatan integralistik yang diterapkan di SMP IT Salman Al-Farizi Yogyakarta mampu menjadi media alternatif inovasi pendidikan Islam di era milenial. Bahkan pendekatan integralistik ini akan menjadikan akidah Islamiyah sebagai fondasinya. Oleh sebab itu, pendidikan Islam di tengah-tengah arus milenial harus di inovasi dengan menggunakan pendekatan integralistik. Dengan demikian, pendidikan Islam akan mampu menciptakan peserta didik yang berkepribadian Islam sekaligus pintar dan terampil dalam menguasai sains dan teknologi.
\end{abstract}

Cara mensitasi artikel:

Hasanah, N. Z., \& Zakly, D. S. (2021). Pendekatan integralistik sebagai media alternatif inovasi pendidikan Islam di era milenial. Asatiza: Jurnal Pendidikan, 2(3), 151-160. https://doi.org/10.46963/asatiza.v2i3.384

PENDAHULUAN

Pendidikan hakikatnya adalah menyediakan memungkinkan setiap peserta didik mengembangkan bakat, minat, dan kemampuannya secara optimal dan utuh yang mencakup aspek kognitif, afektif, dan psikomotorik. (Muhibbin Syah, 2013,

Editorial Address: Kampus STAI Auliaurrasyidin Tembilahan 
h.6). Suksesnya pendidikan, tidak lepas dari peran orang tua, sekolah, dan masyarakat pula. Dalam keluarga, orang tua berperan menanamkan pendidikan moral dan tanggungjawab untuk bersikap yang baik. Peran sekolah lebih pada penanaman materi pengajaran yang disisipi dengan nilai-nilai pembentukan jati diri yang konstruktif. Sedangkan peran masyarakat ialah sebagai medan praktis, dimana seorang anak banyak berinteraksi dengan orang-orang di sekitarnya dan terjadi dialog yang secara tidak sadar terdapat pola pendidikan didalamnya. (Heru Kurniawan, 2016, h.41-42). Sebagaimana yang dikatakan oleh Bafadal, bahwa fungsi keluarga, sekolah, dan masyarakat bagaikan tiga tungku sejarangan yang merupakan tiga pilar budaya yang luluh dan padu menjadi satu untuk saling menguatkan. (Bafadal, 2013, h.366).

Pendekatan secara integratif ini sudah seharusnya menjadi tradisi keilmuan dalam dunia pendidikan Islam di Indonesia karena pendekatan multidisiplin dan multi perspektif ini lah yang akan menjadi salah satu pengaruh besar dalam meningkatkan pendidikan Islam. Bersamaan dengan hadirnya inovasi ini pula dapat membuat metode berpikir dan berijtihad dalam pendidikan Islam pun tidak akan pernah tertutup. (Qodir, 2016).

Umaimah (2017) berpendapat bahwa pendekatan integralistik atau yang dikenal juga dengan istilah pendekatan secara holistik (keseluruhan) adalah pendekatan dari guru kepada anak didik dengan pendekatan secara menyeluruh dengan adanya paduan antara tradisi ilmuilmu berdasarkan kebutuhan suatu lembaga pendidikan sehingga tidak adanya dikotomi ilmu pengetahuan, melainkan berpegang teguh kepada nilainilai agama.

Faktor utama yang menjadi pendukung keberhasilan pendekatan integralistik di sekolah ini ialah terdapatnya upaya saling memberikan pengaruh, saling mengarahkan, dan saling mengawasi juga saling berdisiplin baik bagi para guru juga peserta didik. Maka dari itu, dapat diketahui bahwa keberhasilan pendekatan integralistik ini haruslah dilakukan secara dua arah, yaitu oleh para guru dan peserta didik sehingga pendekatan integralistik ini dapat dijalankan secara konsisten dan dapat tercapai sesuai dengan tujuan yang diharapkan. (Hikmat, 2019, h.19). Sebagaimana ungkapan dari Yusuf Qardhawi bahwa Islam sebagai asas rabbaniyyah adalah kemurnian ajaran dari Allah seratus persen dari segi akidah, ibadah, akhlak atau adab, serta syariatnya, dan bukan hanya kepada pengertiannya secara ta'rifaat. (Samsirin, 2017).

Apalagi di era saat ini, pesatnya kemajuan ilmu dan teknologi serta komunikasi, semakin mempercepat proses globalisasi di muka bumi. Bersamaan dengan hal itu, muncul masa atau zaman baru pasca adanya globalisasi yaitu era milenial. Munculnya era milenial menjadi sebuah bentuk tantangan sekaligus menjadi harapan bagi semua orang. Di zaman ini, generasi hidup tanpa jarak, ruang dan waktu. Sehingga, ruang, jarak dan waktu dapat dilampauinya secara singkat dalam satu genggaman. (Abuddin Nata, 2018). 
Munculnya era milenial ini secara tidak langsung membawa dampak terutama dalam proses keberlangsungan pendidikan Islam. Islam yang seharusnya menjadi pedoman seorang muslim dalam bertingkah laku semasa hidup kini telah dilupakan. Kenyataannya, umat muslim yang telah jauh dari Islam ini bebas bertindak semaunya dan sesuka hatinya, bahkan semua penemuan yang mengagungkan itu telah menjadikan manusia untuk mendukung selera hawa nafsunya. Karena itulah umat muslim di era ini menjunjung tinggi nilai-nilai liberalisme kebebasan. Akibat dari kehidupan yang demikian itu, manusia menjadi bebas berbuat tanpa melihat batas halal dan haram.

Di zaman modern ini, pendidikan Islam hanya berfokus pada tujuan individualistis. Ketergantungan dan kecenderungan pada teknologi dan komunikasi menjadi fenomena yang sering terlihat. Generasi muda Islam kini mulai banyak yang menghabiskan waktunya di depan telepon genggamnya. Silaturahmi antara pendidik dengan anak didik, pembinaan secara tatap muka dan berdiskusi menjadi hal yang jarang terlihat. Akhirnya umat muslim telah jauh dari Islam, sebab menjauhkan agama dari kehidupan.

Mahyuddin Barni juga berpendapat bahwa generasi milenial memiliki sifat dan perilaku yang berbeda dari generasi yang sebelumnya. Menurut Faturohman dalam Barni, ada tujuh sifat dan perilaku dari generasi milenial, yaitu. generasi ini lebih mempercayai informasi interaktif ketimbang informasi searah, generasi milenial lebih memilih telepon seluler ketimbang TV, generasi milenial wajib memiliki media sosial, generasi milenial kurang minat membaca secara konvensional, generasi milenial cenderung tidak loyal namun bekerja efektif, generasi milenial mulai banyak melakukan transaksi secara cashless, serta generasi milenial lebih melek teknologi ketimbang orang tua mereka. (Mahyuddin Barni, 2019).

Selain itu, dalam beramal pun umat muslim tidak pernah peduli apakah Islam membolehkan aktivitas itu atau tidak, yang penting seru sekedar karena asyik supaya tidak dibilang ketinggalan zaman. Misalnya, berkerudung agar terlihat cantik, gibah dimana-mana supaya up to date, dan lain sebagainya. Inilah gambaran gaya bebas itu. Tidak peduli lagi apakah Allah suka dengan aktivitas tersebut atau tidak. Akhirnya, karena saking jauhnya umat dari Islam, banyak muslim yang tidak memahami bagaimana gambaran kepribadian yang seharusnya terbentuk pada diri seorang muslim.

Pendidikan Islam seharusnya bertugas untuk mengawali umat manusia dalam siklus perubahan hidupnya dari berbagai tahapan dengan seimbang dan dapat meluruskan mereka supaya memiliki landasan akidah, tauhid dan akhlak yang baik, yang mana dari hasil penerapannya akan menjadi inspirasi untuk dapat dipraktikkan dan supaya untuk menjadi pengingat serta pedoman hidup yang baik. (Ahmad Husain Ritoga, 2018). Adanya ruang akibat kemajuan teknologi yang canggih menghapuskan sekat-sekat yang ada, bahkan tidak ada lagi batas antara negara, bangsa dan kelas. Fenomena dan dinamika ini telah masuk ke ruang-ruang 
sempit, sehingga masuknya globalisasi di Indonesia ini melahirkan generasi gadget. Istilah inilah yang sering disebut dengan generasi milenial. (Yanuar Surya Putra, 2016).

Menyikapi fenomena di era milenial yang semakin merajalela dan pesat ini, maka sudah sepantasnya pendidikan Islam harus mampu mengembangkan kemampuan dalam berkompetisi, mampu dalam merealisasikan sikap yang kreatif dan inovatif, serta mampu mengupgrade dirinya untuk berani menghadapi kehidupan yang global ini. (Nur Khalis, 2019).

Masalah moral seperti korupsi, perkosaan dan penipuan. Masalah spiritual seperti tidak merasa berdosa kalau berbuat maksiat dan kesalahan, dan selalu merasa tidak puas. Masalah sosial seperti konflik bahkan penjajahan dan peperangan, tidak dapat diatasi oleh ilmu dan teknologi canggih semata. Sebagaimana yang diungkapkan oleh Abuddin Nata yang mengasumsikan bahwa panca indera, akal, ilmu pengetahuan dan teknologi tidak dapat menyelesaikan masalah yang amat krusial dan luas, karena semua itu bukanlah tujuan, melainkan hanya alat.

Jika pendidikan Islam tidak memiliki filter yang kuat terhadap perkembangan era milenial maka generasi ini akan terpapar milenial effect, yaitu maraknya berbagai teknologi yang canggih akan membuat sesuatu itu menjadi hal yang diagung-agungkan. Oleh karenanya, pendidikan Islam saat ini perlu ditata dengan merujuk pada akidah Islam agar dapat diletakkan sesuai kedudukannya sehingga memungkinkan untuk mendapatkan peluang besar dalam mengambil peluang yang ada.

Pendidikan Islam di Indonesia memiliki orientasi untuk mencetak generasi yang Islami serta menjadikan akidah Islamiyah sebagai pondasi serta nilai keimanan dan ketakwaan menjadi fokus utamanya. Dengan hal ini, maka untuk mengatasi hal tersebut, pendidikan Islam di tengah arus milenial ini harus diinovasi dengan menggunakan pendekatan integralistik sehingga akan mencetak generasi yang mampu bersaing di tengah gejolak milenial.

Salah satu sekolah di Kecamatan Ngaglik yang menjadi model pendekatan integralistik adalah di SMP IT Salman AlFarizi Yogyakarta. Namun, di sekitar Kecamatan Ngaglik ini belum semua sekolah yang menerapkan strategi pendekatan integralistik. Dengan adanya pendekatan integralistik, maka pendidikan Islam akan mampu menciptakan peserta didik yang berkepribadian Islam sekaligus pintar dan terampil dalam menguasai sains teknologi yang diperlukan dalam kehidupan.

Penelitian ini bertujuan untuk menginterpretasikan mengenai pendekatan integralistik sebagai media alternatif inovasi pendidikan Islam. Setelah selesai penelitian ini, diharapkan dapat diketahui proses penerapan pendekatan integralistik sehingga pada akhirnya dapat dijadikan sebagai media alternatif dalam inovasi pendidikan Islam di era milenial. 


\section{METODE}

Jenis penelitian ini adalah penelitian kualitatif. Peneliti menggunakan jenis penelitian kualitatif karena dengan penelitian kualitatif ini peneliti dapat menekankan pada banyak aspek dari satu variabel jika mungkin dijadikan permasalahan yang diteliti lebih mendalam serta lebih dekat dengan data yang diambil karena peneliti mengikuti aktivitas informan. Sedangkan pendekatan penelitian yang digunakan adalah penelitian deskriptif kualitatif yang mana penelitian ini memberikan penjelasan atau uraian terhadap objek yang diteliti.

Penelitian ini ditujukan untuk menjelaskan atau menginterpretasikan mengenai pendekatan integralistik sebagai media alternatif inovasi pendidikan Islam di era millenial. Dengan demikian, peneliti dapat menganalisis dan mendeskripsikan mengenai fakta-fakta implementasi pendekatan integralistik sebagai media alternatif inovasi pendidikan Islam.

SMP IT Salman Al-Farizi Yogyakarta yang bertempatkan di jalan Kaliurang Km.12,5 Mriyunan, Sardonoharjo, Ngaglik, Sleman, Yogyakarta adalah lokasi yang dipilih peneliti untuk melaksanakan penelitian, karena dari berbagai macam sekolah di tingkat Kecamatan Ngaglik, hanya SMP IT Salman Al-Farizi yang menerapkan pendekatan integralistik sebagai media alternatif dalam inovasi pendidikan Islam.

Populasi dalam penelitian ini adalah seluruh guru-guru di SMP IT Salman AlFarizi Yogyakarta. Sedangkan sampel dalam penelitian ini adalah guru yang berkecimpung langsung dengan peserta didik dalam menerapkan pendekatan integralistik sebagai media alternatif inovasi pendidikan Islam di era millenial.

Data yang digunakan dalam penelitian ini dapat diklasifikasikan menjadi: (1) Data primer, yaitu data yang diperoleh secara langsung dari objek yang diteliti. Termasuk di dalam data primer adalah hasil wawancara dengan informan dan dokumen-dokumen yang berasal dari SMP IT Salman Al-Farizi. (2) Data sekunder, yaitu data yang diperoleh dari selain sumber primer (sumber kedua, ketiga, dst). Termasuk dalam data sekunder adalah data pendukung yang berasal dari jurnal, buku, majalah, surat kabar, artikel, internet, dan media sosial yang berhubungan dengan objek penelitian.

Dalam penelitian ini, peneliti menggunakan uji keabsahan data dengan uji kredibilitas dan dengan cara triangulasi. Triangulasi merupakan pengecekan data dari berbagai sumber dengan berbagai cara dan waktu. Ada tiga jenis triangulasi dalam penelitian kualitatif, yaitu triangulasi sumber, triangulasi teknik, dan triangulasi waktu. Namun, peneliti hanya akan menggunakan dua cara triangulasi yaitu: 1) Triangulasi sumber, untuk menguji kredibilitas data dengan cara mengecek data yang diperoleh dari beberapa sumber. 2) Triangulasi Teknik, untuk menguji kredibilitas dengan cara mengecek data kepada sumber yang sama dengan teknik yang berbeda. Jika cara tersebut menghasilkan data yang berbeda, maka dilakukan diskusi dengan partisipan yang bersangkutan untuk mendapatkan data yang relevan dan dapat diuji. (Sugiyono, 2017, h.274). 
Dalam penelitian ini, prosedur pengumpulan data yang dilakukan oleh penulis adalah sebagai berikut: (1) Metode wawancara. Dalam penelitian ini, penulis berusaha mencari informasi melalui wawancara dengan informan terkait. Berkaitan dengan penelitian kualitatif, maka penulis menentukan informan yang diharapkan dapat memberikan informasi sesuai dengan fokus penelitian, yaitu guru SMP IT Salman Al-Farizi. Informan ini dipilih berdasarkan kriteria tertentu, diantaranya bahwa informan tidak hanya sekedar tahu dan dapat memberikan informasi, akan tetapi juga telah menghayati secara sungguh-sungguh sebagai akibat dari keterlibatan yang cukup lama dengan kegiatan yang bersangkutan. (2) Metode observasi. Dalam hal ini, peneliti mengamati secara langsung ke objek penelitian dengan tujuan untuk memperoleh data yang akurat sehingga akan tercapai suatu pembahasan dalam penelitian ini. Peneliti memperhatikan apa yang terjadi, mendengarkan apa yang dikatakan, mempertanyakan informasi dan mempelajari dokumen yang dimiliki informan. (Sugiyono, 2017, h.101). (3) Metode dokumentasi, yaitu teknik pengumpulan data dengan menghimpun dan menganalisis dokumen-dokumen baik dokumen yang berbentuk tulisan atau gambar. Dokumentasi dilakukan dengan menelaah dokumen-dokumen yang berkaitan dengan penelitian, termasuk sumber-sumber sekunder.

Data yang diperoleh dianalisis dengan teknik analisis isi (content analysis). Teknik ini mencakup tiga syarat, yaitu: obyektifitas, pendekatan sistematis, dan generalisasi. (Bungin Burhan, 2013, h.61). Adapun metode analisis data yang digunakan dalam penelitian ini adalah bersifat induktif, yaitu analisis berdasarkan data yang diperoleh. Untuk menganalisis data, peneliti menggunakan model analisis data dari Miles, Huberman dan Saldana yang dikenal sebagai model interaktif. Miles, Huberman dan Saldana menyatakan bahwa kegiatan analisis data ini merupakan kegiatan yang saling berhubungan pada sebelum, selama, dan sesudah pengumpulan data dalam bentuk sejajar untuk membangun wawasan umum yang disebut analisis. (Sugiyono, 2017, h.147-152).

Kegiatan analisis data dengan model interaktif ini meliputi: 1) Kondensasi data, proses ini merujuk pada proses pemilihan data, memfokuskan data yang diperoleh, menyederhanakan data, mengabstraksikan data, dan mentransformasikan data yang mendekati keseluruhan bagian dari dokumen, dan materi-materi empiris. 2) Penyajian data, yaitu sebuah proses pengorganisasian, penyatuan, dan informasi yang disimpulkan. 3) Penarikan kesimpulan, pada proses ini, peneliti meneliti seperti mencari pemahaman yang tidak memiliki pola mencatat keteraturan penjelasan, dan alur sebab akibat yang tahap akhirnya disimpulkan keseluruhan data yang diperoleh. (Saldana, dkk., 2014, h.12-14).

\section{HASIL DAN PEMBAHASAN}

SMP IT Salman al-Farizi Yogyakarta adalah salah satu lembaga pendidikan yang mampu mempertahankan integritasnya dalam melakukan pendekatan integralistik. Bentuk pendekatan integralistik di SMP IT 
Salman Al-Farizi terjadi pada saat komponen kegiatan di dalam sekolah terlibat dalam suatu proses yang bersifat continue. Adapun faktor-faktor yang membuat sekolah ini berdiri yaitu berkat integritas serta kegigihannya dalam membangun sekolah yang mana ilmu umum dan ilmu agama bisa bersatu dan keyakinan bahwa ilmu agama merupakan ilmu pokok yang harus diterapkan sejak awal.

Sekolah ini pada dasarnya hanya berfokus pada aspek ilmu agama dan ilmu umum. Dimana guru selalu memberikan mentoring setiap harinya kepada peserta didik. Selain itu, di sekolah ini ada silaturahmi, pembinaan secara tatap muka, dan diskusi secara langsung, antara pendidik dengan anak didik. Proses pembelajaran di sekolah ini yaitu dengan cara memberikan konsep atau pemikiran kepada siswa, lalu siswa menerima atau membenarkan ilmu tersebut melalui proses berfikir yang dilakukannya. Ilmu yang telah dipahami, diarahkan untuk membangun kesadaran sekaligus sebagai landasan sikap dan perilakunya.

Materi pembelajaran yang diterapkan di sekolah ini berbasis realitas yang terindera oleh anak, sehingga pembelajaran berproses membangun dan meningkatkan kemampuan berfikir anak. Sebab, materi pelajaran yang diberikan di sekolah ini sesuai dengan tahap perkembangan anak. Ilmu yang diajarkan pun hanya yang diperlukan anak pada usia perkembangannya, sehingga dengan begitu anak didik akan mudah memahami dan bisa mengamalkannya.

Dalam proses pendidikannya, setiap kelas ada guru yang mengampu lebih dari satu. Sebab, jika gurunya banyak maka siswa akan lebih untuk diperhatikan oleh gurunya. Untuk tempat menghafal AlQuran, anak-anak diberi kebebasan, karena untuk menghafal diperlukan tempat yang tenang. Sedangkan untuk metode pembelajaran yang dipraktikkan adalah lebih ke praktik dan ceramah sesuai dengan pelajarannya. Misalnya, dalam pelajaran IPA lebih ke praktik dengan cara turun ke alam langsung, karena letak sekolah ini berdekatan dengan sawah. Sedangkan untuk keagamaan lebih ke ceramah ataupun presentasi.

Penerapan pendidikan di sekolah ini berbentuk asrama, sehingga kedekatan siswa dan guru dapat dikatakan cukup intens dikarenakan mereka hidup bersama bahkan beraktivitas selama hampir 24 jam. Juga adanya penekanan ajaran agama yang terus dipantau, sehingga sulit bagi pihak luar untuk dapat memberikan interferensinya. Hal ini lah yang membuat sekolah ini dapat mempertahankan integritasnya dalam melakukan pendekatan integralistik.

Selain itu, Allah juga menyeru amal makruf nahi munkar, dan hal tersebut telah menjadi pedoman pendidikan di SMP IT Salman Al-Farizi yang berhasil menciptakan lingkungan sekolah yang kondusif dengan dipenuhi atmosfer nilainilai islami. Implementasi pendekatan integralistik ini, bukanlah hal yang mudah. Tidak mudah, bukan berarti tidak mungkin untuk dikembangkan menjadi suatu proyek pendidikan dalam meningkatkan kualitas ilmu pengetahuan Islam pada peserta didiknya. 
Pendekatan Integralistik di SMP IT Salman Al-Farizi

SMP IT Salman Al-Farizi Boarding

School mempunyai satu program unggulan, yaitu Program Takhasus Al Qur'an. Program ini dirancang untuk mendidik siswa menjadi para penghafal $\mathrm{Al}$ Qur'an. Sesuai dengan namanya, program ini mempunyai aktivitas dan target khusus. Program khusus tersebut adalah siswa harus dapat menyelesaikan 30 juz dalam waktu 1 tahun. Berbeda dengan program reguler. Program reguler untuk siswa di sekolah ini, hanya mempunyai targetan hafalan 10 juz dalam waktu tiga tahun. Program takhasus mengalami beberapa perubahan desain dari desain semula. Pada awal mula program ini diselenggarakan yaitu tahun 2016, program ini di desain untuk mencatak hafidz dan hafidzah dalam kurun waktu 3 tahun. Namun satu tahun kemudian, pada tahun ajaran 2017/2018 program ini ditetapkan menjadi 1 tahun saja. Sehingga siswa yang mengikuti program ini harus menyelesaikan hafalan Al Qur'an selama satu tahun.

Mungkin sangat mustahil, jika harus menghafalkan 30 juz Al Qur'an dengan waktu yang sangat singkat. Namun faktanya, belum ada satu tahun program ini berjalan, siswa di SMP IT Salman AlFariz sudah mampu menjadi seorang hafidz. Satu siswa putri bernama Inas Amatullah berhasil menyelesaikan hafalannya pada tanggal 8 November 2017. Hampir program ini baru berjalan 4 bulan, Inas telah menyelesaikan hafalannya. Hal ini membuktikan bahwa program ini bukan program khayalan dan tanpa perhitungan. Juga menegaskan bahwa program ini adalah program yang sangat realistis dalam menciptakan hafidz dan hafidzah.

Takhasus Qur'an mempunyai target harian yang harus dicapai oleh siswa yang mengikuti program ini. Target hafalan setiap hari adalah setor 4 halaman atau 2 lembar. Para siswa memakai mushaf Qur'an Pojok 15 baris, setiap 1 juz Al Qur'an terdiri dari 10 lembar. Sehingga tiap pekannya, siswa harus menyetorkan 1 Juz hafalan Al Qur'an. Jika dalam satu pekan siswa dapat menyetorkan hafalan $\mathrm{Al}$ Qur'an 1 juz secara istiqomah, mereka dapat menyelesaikan 30 juz dalam waktu delapan bulan saja.

Pembelajaran Al-Qur'an yang diterapkan di sekolah ini, menjadi materi pokok pembelajaran. Mulai dari menghafal Al-Quran, membaca Al-Qur'an dengan tartil, memahami isi Al-Qur'an, dan memahami makna lafazh Al-Qur'an. Selanjutnya mempelajari apa yang diperintahkan Al-Qur'an, yaitu As-Sunnah (Al-Hadits) serta kadar-kadar dan manfaat alam semesta ciptaan Allah SWT (saintek).

Salah satu dorongan dari masyarakat, dengan adanya pendekatan integralistik sebagai inovasi yang diterapkan di sekolah ini adalah orang tua kebanyakan menyekolahkan anaknya disini. Karena di sekolah ini, anak-anak juga diajarkan pendidikan agama dan ilmu umum yang direalisasikan melalui pembinaan atau mentoring yang dilakukan setiap harinya. Jadi, sudah tidak diragukan lagi bahwa dengan adanya pembinaan ini, maka pendidikan islam akan mampu menciptakan peserta didik yang berkepribadian islam sekaligus pintar dalam faqih fiddin dan terampil dalam 
menguasai sains teknologi yang diperlukan dalam kehidupan.

Selain itu, peraturan yang diterapkan di sekolah ini cenderung bersifat mengikat, ditambah dengan sistem sekolah yang berbasis asrama, sehingga seluruh kegiatan akademik maupun nonakademik siswa dapat dipantau selama hampir 24 jam penuh. Salah satu contoh bentuk kedisiplinan yang diterapkan ialah mewajibkan seluruh siswa asrama untuk bangun pagi, wajib mandi sebelum shubuh, jalan jongkok ataupun lari keliling lapangan apabila telat masuk gerbang sekolah, dan panjang rambut maksimal 2 $\mathrm{cm}$ untuk siswa laki-laki apabila melanggar maka akan digundul.

Fondasi terkuat yang ada di sekolah ini adalah teguh mempertahankan nilainilai pendekatan integralistik pada anak didiknya. Hal itu terletak pada visi dan misi sekolah itu sendiri yaitu visi yang pertama, terwujudnya sekolah Islam yang kondusif (sekolah yang berasrama, lingkungan bersih, sehat, aman, dan nyaman, serta suasana sekolah yang berlingkungan Qur'ani).

Yang kedua, terciptanya sekolah yang bermutu (kurikulum terintegrasi, fasilitas pendidikan yang memadai, berprestasi di bidang akademik dan non akademik, tenaga pendidik yang profesional.

Yang ketiga, terwujudnya sekolah yang unggul dalam hal (menguasai kemampuan diniyah dengan baik, mampu memahami dasar-dasar berbahasa asing bahasa Inggris dan bahasa Arab dengan baik, mampu menggunakan IPTEK, mampu membaca Al-Qur'an dengan tartil, mampu menghafal Al-Qur'an minimal 10 juz, dan mampu mencetak generasi yang berkepribadian Islami.

Adapun misi sekolah itu sendiri yaitu, menyelenggarakan pendidikan yang sistematis, terarah, dan profesional. Membekali peserta didik dengan nilainilai Al-Qur'an, As-Sunnah, dan Pancasila. Membina peserta didik unggul dalam bidang akademik maupun non akademik. Mewujudkan lingkungan pendidikan yang bersih, sehat, nyaman, dan aman. Membekali peserta didik agar unggul dalam ilmu pengetahuan dan teknologi.

Dengan adanya visi misi sekolah tersebut, integritas sekolah ini dalam memegang teguh ajaran Islam dapat dibuktikan dari beberapa pencapaian yang sudah diraih antara lain, menciptakan siswa yang berkepribadian islam, berprestasi, dan berjiwa qur'ani yang menguasai faqih fiddin.

Dengan demikian, pendekatan integralistik sangat dipercaya untuk mampu berkiprah sebagai media alternatif dalam inovasi pendidikan islam di era millenial saat ini, dengan menjadikan aqidah islamiyah sebagai pondasi. Keimanan dan ketakwaan para guru dan anak didik menjadi fokus utamanya. Memperjelas kekontrasan antara halal dan haram akan ditanamkan kepada anak didik, sehingga dengan begitu anak didik akan menjadikan itu sebagai standar hidup bagi mereka. Oleh sebab itu, pendidikan islam di tengah-tengah arus millenial harus di inovasi dengan menggunakan pendekatan integralistik sehingga akan mampu tampil dan bersaing di tengah gelombang millenial. 
Nur Zaytun Hasanah, \& Dhiko Saifuddin Zakly

Dengan adanya pendekatan integralistik, maka pendidikan islam akan mampu menciptakan peserta didik yang berkepribadian islam, sekaligus pintar dan terampil dalam menguasai sains teknologi yang diperlukan dalam kehidupan. Namun, di sekitar Kecamatan Ngaglik belum semua sekolah yang menerapkan strategi pendekatan integralistik. Maka dari itu, peneliti melihat bahwa adanya pendekatan integralistik di SMP IT Salman Al-Farizi Yogyakarta, menjadi salah satu keunikan sebagai bentuk inovasi pendidikan di Indonesia.

\section{SIMPULAN}

Berdasarkan hasil penelitian dan pembahasan yang telah penulis paparkan di atas, maka dapat disimpulkan bahwa hasil dari pendekatan integralistik di SMP IT Salman Al-Farizi Yogyakarta adalah terciptanya lulusan peserta didik yang berkepribadian islam, menguasai faqih fiddin, berprestasi (hafal Qur'an), dan berjiwa qur'ani yang direalisasikan melalui pembinaan atau mentoring yang dilakukan setiap harinya.

Nilai-nilai pendekatan integralistik pada anak didik yaitu terletak pada visi untuk terwujudnya sekolah itu sendiri dengan sistem asrama yang kondusif, bermutu, dan modern untuk menciptakan generasi unggul yang Islami dan berstandar sekolah nasional.

Oleh karena itulah, pendidikan integralistik adalah satu-satunya pendekatan yang sangat penting untuk diterapkan di sekolah-sekolah. Sebab, kalau melihat perkembangan zaman di era millenial saat ini, pendidikan Islam perlu ditata dengan merujuk pada aqidah Islam, agar dapat diletakkan sesuai kedudukannya. Pendidikan Islam yang hanya berfokus pada tujuan Ridho Ilahi, menjadikan dunia ini dalam genggaman, sehingga akhirat menjadi fokus tempat kembali yaitu surga atau neraka. Sehingga dengan begitu akan memungkinkan untuk mendapatkan peluang besar dalam mengambil peluang yang ada demi meningkatkan kualitas pendidikan Islam di Indonesia.

Dengan demikian, pendidikan Islam akan mampu menciptakan peserta didik yang berkepribadian Islam sekaligus pintar dalam menguasai ilmu agama dan terampil dalam menguasai sains teknologi yang diperlukan dalam kehidupan.

\section{REFERENSI}

Bafadal. (2013). Strategi Pembelajaran. Yogyakarta. Ar-Ruzz Media.

Barni, M. (2019). Tantangan pendidik di era millennial. Jurnal Transformatif (Islamic Studies), 3(1), 99-116. https://doi.org/10.23971/tf.v3i1.1251

Burhan, B. (2013). Analisis Data Penelitian Kualitatif Pemahaman Filosofis dan Metodologis ke Arah Penguasaan Model Aplikasi. Yogyakarta. Raja Grafindo Persada.

Hikmat. (2019). Manajemen Pendidikan. Bandung. Pustaka Setia.

Khalis, N., \& Akhiruddin, A. (2019). Membaca peluang dan tantangan paradigma baru pendidikan Islam di era millenial. Tarbawiyah: Jurnal Ilmiah Pendidikan, 3(1), 73-89. https://doi.org/10.32332/tarbawiyah. v3i1.1695

Kurniawan H. 2016. Metode Edutainment. Yogyakarta. Ar-Ruzz Media.

Nata, A. (2018). Pendidikan Islam di era milenial. Conciencia, 18(1), 10-28. https://doi.org/https://doi.org/10.191 09/conciencia.v18i1.2436 
Putra, Y.S. (2016). Theoritical review: teori perbedaan generasi. Among Makarti, $\quad 9(2), \quad$ 123-134. http://dx.doi.org/10.52353/ama.v9i2. 142

Qodir, Z. (2016). Mempertimbangkan metode integralistik: Sosiologi untuk kajian islam dan sosial. Jurnal Sosiologi Reflektif, 10(2), 1-14. https://doi.org/10.14421/jsr.v10i2.11 64

Ritonga, A. H., \& Bafadhal, F. (2018). Tantangan dan peluang pendidikan islam pada era milenial. Innovatio: Journal for Religious-Innovation Studies, 18(1), 27-38. https://doi.org/10.30631/innovatio.v $18 \mathrm{i} 1.38$

Saldana, \& Huberman. M. (2014). Qualitative Data Analysis. America. SAGE Publications.

Samsirin, S. (2017). Nilai-nilai pendidikan karakter menurut konsep Yusuf Qardhawi. Educan: Jurnal Pendidikan Islam, l(1). http://dx.doi.org/10.21111/educan.v1 i1.1301

Sugiyono. (2017). Metode Penelitian Ilmu Sosial. Bandung. Alfabeta.

Sugiyono. (2017). Metode Penelitian Kuantitatif, Kualitatif, dan $R \& D$. Bandung. Alfabeta.

Syah M. (2013). Psikologi Belajar Ed Revisi. Jakarta. Rajawali Press.

Umaimah, R. (2017). Pendekatan integralistik pendidikan agama pada sekolah (Reformulasi Filsafat Pendidikan Islam). Transformasi: Jurnal Studi Agama Islam, 10(2), 2435. 